\title{
Ectodermal Dysplasia in child: multidisciplinary management
}

\author{
Displasia Ectodérmica em criança: manejo multidisciplinar \\ Caroline Guimarães Schautz ${ }^{1}$, Larissa Conrado da Silva ${ }^{1}$, Khawana Faker ${ }^{2}$, Mônica Almeida Tostes ${ }^{2}$, Viviane Cancio ${ }^{2}$ \\ 1 - Fluminense Federal University - Niterói - RJ - Brazil. \\ 2 - Paediatric Dentistry Department - School of Dentistry - Fluminense Federal University - Niterói - RJ - Brazil.
}

\section{ABSTRACT}

Ectodermal Dysplasia (ED) represents a group of hereditary conditions in which anatomical structures derived from the ectoderm show defects in its development. It is observed aplasia or hypoplasia of the tissues, among them the changes of dental relevance, as the anomalies regarding the number and morphology of the teeth. Due to the particularity of the cases, the dental surgeon must adapt the operative techniques and the choice of dental materials to each individual, according to the perceived need and condition. The objective of the present study is to report the clinical case of a 10 - year old male patient with ectodermal dysplasia who was attended in the discipline of Patients with Special Needs of Dentistry of the Federal University of Fluminense and its multidisciplinary aspects.

\section{KEYWORDS}

Children with disabilities; Dental care for disabled; Ectodermal dysplasia; Oral rehabilitation.

\section{RESUMO}

A Displasia Ectodérmica (DE) representa um grupo de condições hereditárias em que estruturas anatômicas derivadas do ectoderma apresentam defeitos em seu desenvolvimento. Observa-se aplasia ou hipoplasia dos tecidos, dentre eles as alterações de relevância dentária, como as anomalias quanto ao número e morfologia dos dentes. Devido à particularidade dos casos, o cirurgião-dentista deve adaptar as técnicas operatórias e a escolha dos materiais dentários a cada indivíduo, de acordo com a necessidade e condição percebida. O objetivo do presente estudo é relatar o caso clínico de um paciente do sexo masculino, de 10 anos de idade, portador de displasia ectodérmica, atendido na disciplina de Portadores de Necessidades Especiais de Odontologia da Universidade Federal Fluminense e seus aspectos multidisciplinares.

\section{PALAVRAS-CHAVE}

Crianças com defi ciência; Assistência odontológica para defi cientes; Displasia ectodérmica; Reabilitação oral.

\section{INTRODUCTION}

- ctodermal Dysplasia (ED) represents a group of hereditary conditions in which two or more anatomical structures derived from the ectoderm show deficits in their development. Thus, aplasia or hypoplasia of the tissues, such as skin, hair, nails, teeth or sweat glands can be observed. Its prevalence in the population varies from $1: 10.000$ to $1: 100.000$ births and the proportion between the genders is five men for a woman [1-3].
The inheritance of this disorder can occur in any of a number of genetic patterns, including autosomal dominant, autosomal recessive and X-linked. Although more than 170 different subtypes of ED have been defined, Anhidrotic ectodermal dysplasia (AED) and Hypohydrotic (HED) are the two types [35]. In its hypohidrotic form, the DE presents/ displays absence or significant reduction of the number of sweat glands, where as in its anhidrotic form does not occur alteration of the sudoriparous glands [6]. 
The triad of nail dystrophy (oncodysplasia), alopecia or hypotrichosis (scarce, thin and clear hair on the scalp and eyebrows) and hyperkeratosis palmoplantaris is often accompanied by a lack of sweat glands (hypohidrosis) and partial or complete absence of deciduous and / or permanent teeth. Its incidence is estimated in 1: 100,000 affected male born.

Due to the particularity of the cases, the dental surgeon must adapt to the psychological approach, the operative techniques and the choice of dental materials to each individual, according to the perceived need and condition [7]. In addition, its role is extremely important due to the aesthetics of the patient with this disorder, especially in childhood in which the child begins the process of socialization in the environment in which he lives. The objective of this study was to report the case of a 10-year-old male patient with ectodermal dysplasia who was treated in the discipline of Patients with Special Needs of the Dentistry of the Federal University of Fluminense.

\section{CASE REPORT}

A 10-year-old male patient sought care at the Special Needs Patient Clinic accompanied by the mother. The main complaint was maladaptive and broken prostheses. In anamnesis, current and past medical history did not reveal significant information and overall health status was reported as normal. Prenatal, natal and postnatal histories were also not relevant. In the family medical history, the mother reported being the carrier of the disease, as well as the grandmother and the patient's uncle, with no sweating. These facts show the recessive ectodermal dysplasia associated with X. Still reported by the mother, the patient at birth had a fever and to date has recurrent fevers. With the diagnosis of a geneticist, hypohidrotic ectodermal dysplasia was observed, in which there is no sweating.

At the oral examination, the patient had teeth 11 and 21 with diastemas and altered but corrected form with resin composite, teeth 53 and 63 and absence of a border in the upper and lower posterior region. The panoramic radiographic examination revealed the absence of teeth $55,54,52,51,61,62,64$, $65,75,74,73,72,71,81,82,83,84,85,12$, $22,24,25,35,34,32,31,41,42,44$ and 45 and the presence of the included teeth 13, 23, 33 and 43 (Figure 1).

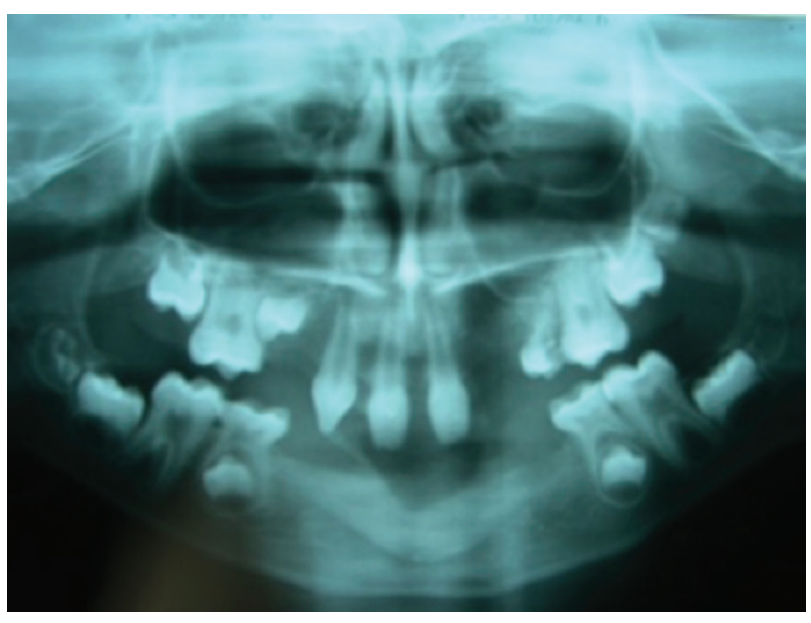

Figure 1 - Panoramic radiographic examination of the patient.

At the oral examination, the patient had thin, parched hair, thin, dry skin, subtly everted lips, discrete fissures around the mouth and eyes, a saddle nose, and prominent supraciliary regions. There was insufficient space for prosthetic reconstruction due to the consequent reduction of the perimeter of the upper and lower arches. The patient presented phonation and atypical swallowing and unsatisfactory esthetics (Figure 2).

Due to poor adaptation of the prosthesis used by the patient, the first procedure was the molding of the upper and lower arches to obtain a study model. The extraction of the teeth 53 and 63 and the relapse of the old prosthesis were performed so that the patient could provisionally use it. As an attempt to expose the teeth 13 and 23, in order to have a support for the prosthesis, an incision was made in the canine region, but it was not successful, since they were completely included and 
without force of eruption. As an attempt to close the upper interincisal diastema, a fixed orthodontic appliance was placed through the bonding of brackets on teeth 11 and 21 (Figure 3). After the approach, surgery was performed to expose the teeth 13, 23, 33 and 43 , together with a bucomaxillofacial surgeon (Figures 4 and 5). The surgery was successful and the patient did not have any postoperative complications.

In addition to the orthodontic approach of teeth 11 and 21, these were restored with $3 \mathrm{M}$ photopolymerizable resin microparticulate in colors A2 and E1 (Figure 6). After that, a removable prosthesis was made to finish the rehabilitation treatment.

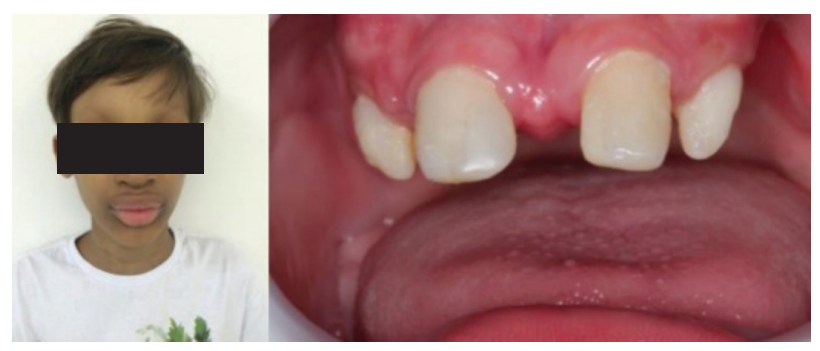

Figure 2 - Face and oral cavity of the patient.

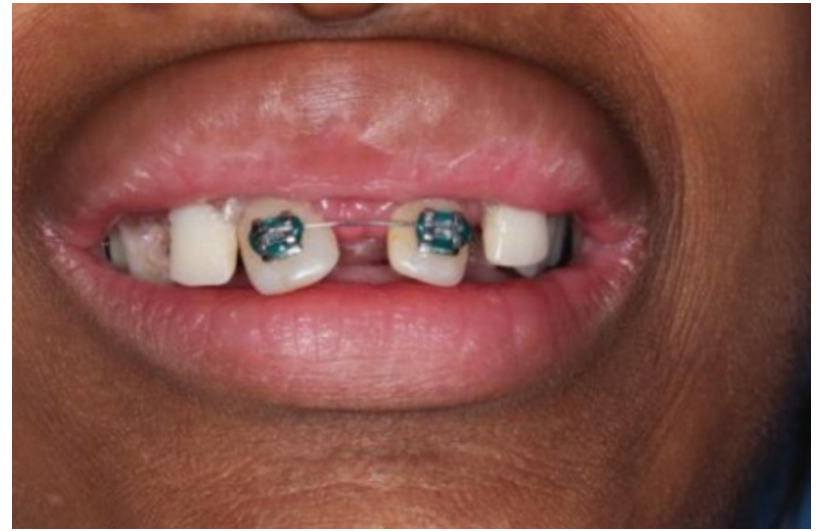

Figure 3 - Placement of brackets to approach the teeth 11 and 21 and closure of the interincisal dysthem.

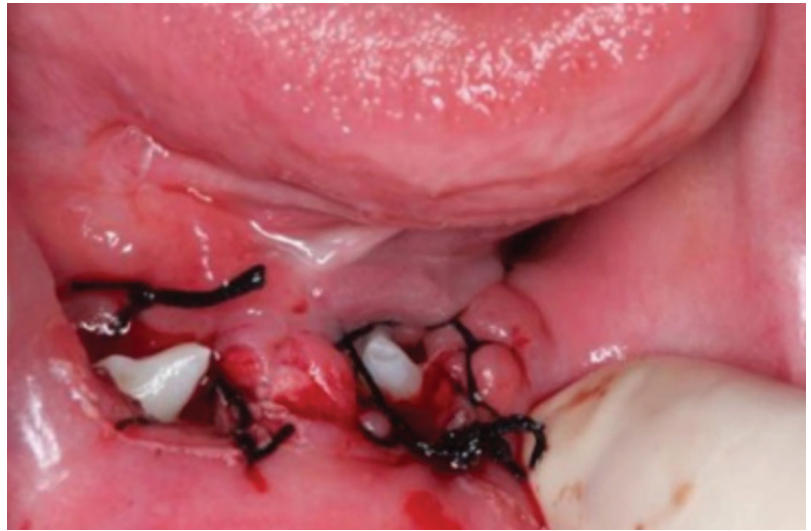

Figure 4 - Surgery for lower canines exposure.

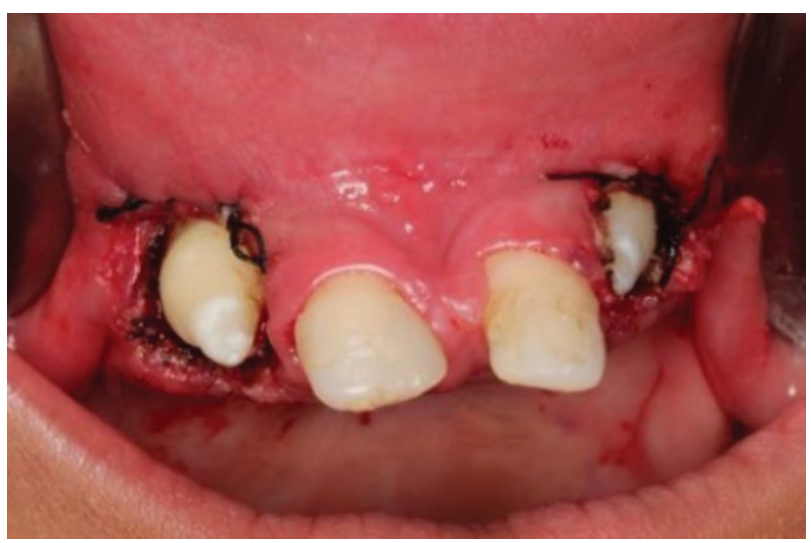

Figure 5 - Surgery for upper canines exposure.

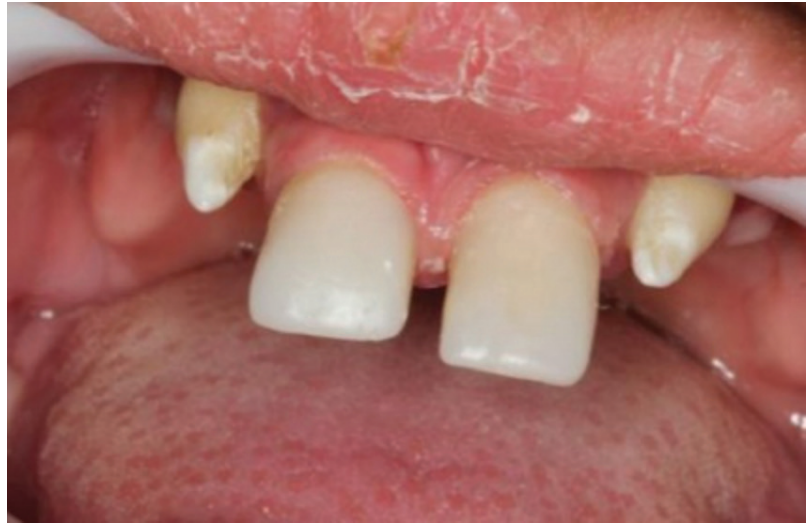

Figure 6 - Restoration with photopolymerizable resin microparticulate of teeth 11 and 21 . 


\section{DISCUSSION}

According to the literature, X-linked recessive hypohydrotic ectodermal dysplasia affects $95 \%$ of the cases of AED, the remaining $5 \%$ of autosomal dominant and autosomal recessive etiology. Its prevalence can vary from $1: 10,000$ to $1: 100,000$, affecting more the male gender [1-3].

Through the reports of the mother and the medical diagnosis, the patient is within one of the most common types of ED, as the literature points out, which is X-linked recessive ectodermal dysplasia, having pictures of pyrexia, hypothyroid triad, hypotrichosis and hypodontia, and other features that identify ED, which is also named as Christ-Siemens-Touraine Syndrome or Hypohidrotic Ectodermal Dysplasia [8]. Felsher, in 1944, changed the anhydrotic adjective into hypohidrotic because people with the hypohidrotic form were not really devoid of all the sweat glands. [9]. Studies state that the hypohidrotic form may have total or partial absence of sweating [10-12].

Pediatric patients with this syndrome manifest hyperthermia regularly, due to the absence of the sweatglands, resulting in anhidrosis [13]. The patient of this study presents facial anomalies such as: saddle nose, protruding lips, malformed ears with oblique implantation, protruding supracilial regions. And due to the modification of the skin, there are fissures around the mouth and eyes, which determines a senile appearance and the hair is scarce and very thin [14].

As for dental absences, Rãducanu, Pãuna and Feraru (2010) discuss the number of dental anomalies that can be seen in individuals with and/or affected by the disease [15]. Ferreira et al. (2012) reported the clinical case of an 11-year-old male melanoderma patient who presented partial anodontia in the oral cavity, with the absence of nine dental elements, especially posterior teeth, with the exception of the absence of the lower central incisors [16]. Vasconcelos et al. (2013), however, reported a case of ED, a 29-year-old male with a presence of 7 dental elements in the oral cavity (13, 11, 21, 23, 33, 32, 43) [17]. And Muzio et al. (2005) presents the case of a leucoderma patient affected by ED, male gender, 7 years old, having in the oral cavity the presence of 4 dental elements [18]. The above-mentioned literary description and case reports support the intraoral clinical findings observed in the patient of the present study.

Rehabilitation of the pediatric patient with ectodermal dysplasia requires extensive knowledge about growth and development, behavioral control of the patient, technique for making prostheses, ability for restorative procedures, and ability to motivate the patient and the parents for the entire treatment period. The treatment is long-term and active, therefore, prostheses should always be adapted to growth, child development and especially, respecting the needs and limitations of the child [19-21].

Silveira (2012) reported the clinical case of a patient where restoration with direct composite resin was used for aesthetic reconstruction of the conoid teeth, and to replace the dental absences were made upper and lower removable partial dentures [22]. Under the justification of being a treatment easy to access, easy to perform, well accepted by the patient, consistent with age and would adequately reestablish masticatory, phonetic and aesthetic functions.

For Ladda, Gangadhar and Bhandari (2013), the removable prosthesis (in its variable types) is the most frequently reported form of treatment for the dental management of ED in infancy, since it can be easily modified during periods of peak growth [23]. For Kaul and Reddy (2008), prostheses, despite their limits, maintain a normal and satisfactory daily diet, thus helping establish a lifelong dietary pattern at an early age [24]. It is known that at the age of nine, children with disabilities begin to observe differences from other children. Therefore, a protein intervention in this age group is valuable in terms of psychological development.

In agreement with the aforementioned authors, the conduct of the current clinical 
case corresponds to the ideas described. For better patient comfort, removable prostheses were made provisionally so that while the final prostheses are produced, they will also be provisional due to the age of the child and also due to the skeletal structure of the same. It is suggested that placement of implants should be done as soon as the child is three years old, allowing the completion of treatment before puberty, and an optimal functional and psychosocial development. However, the placement of integrated bone implants in the growth phase may lead to trauma to permanent tooth germs, tooth eruption disorders, and multidimensional restrictions on craniofacial growth [25].

Due to the annoyance alluded to the patient, implants could not be placed, despite being a proposal for future achievements. Nevertheless, the same was submitted to bucomaxillary facial surgery to expose canines for the purpose of greater retention of prepared prostheses. It is recommended that the patient with ectodermal dysplasia receive multidisciplinary follow-up, involving several professionals such as geneticist, pediatrician, odontopediatrician, bucomaxillo facial surgeon, prosthodontist, otorhinolaryngologist, speech pathologist and psychologist [4].

\section{CONCLUSION}

Ectodermal dysplasia is a syndrome that should be approached in childhood in view of the complexity of the case and the need for continuous follow-up until adulthood. The dentistry specialties, as well as other professionals, are essential for the supply of all the needs presented by the patient, assisting him in his broad biopsychosocial aspect. In this way, the negative impacts on the quality of life of both caregivers and patients are reduced.

\section{REFERENCES}

1. Corrêa MS, Ulson RC, Rodrigues CR, Azevedo AM. Displasia ectodérmica hereditária: revista da literatura com relato de um caso clínico. Rev Paul Odontol. 1997;19(1):30-4.
2. Shigli A, Reddy RP, Hugar SM, Deshpande D. Hypohidrotic ectodermal dysplasia: A unique approach to esthetic and prosthetic management. J Indian Soc Pedod Prev Dent. 2005;23 (1):31-4.

3. Neville BW. Patologia Oral e Maxilofacial. 3th ed. Rio de Janeiro: Elsevier. 2009. $941 \mathrm{p}$.

4. Bakri H, Rapp R, Hadeed G. Clinical management of ectodermal dysplasia. J Clin Pediatr Dent. 1995; 19(3): 167-172.

5. Coskun Y, Bayraktaroglu Z. Pathological case of the month. Arch Pediatr Adolesc Med. 1997;151(7):741-42.

6. Clauss F, Manière MC, Obry F, Waltmann E, Hadj-Rabia S, et al. Dentocraniofacial phenotypes and underlying molecular mechanisms in hypohidrotic ectodermal dysplasia (HED): a review. J Dent Res. 2008;87(12):1089-99.

7. Haddad AS. Odontologia para Pacientes com Necessidades Especiais. São Paulo: Livraria Santos; 2007.719 p.

8. Succi IB, Fontenelle E. Caso para diagnóstico. Displasia ectodérmica: Síndrome de Christ-Siemens-Touraine. An Bras Dermatol. 2009;84(2):194-6.

9. Vaidya S, Risbud M, Kshar A, Ramdurg P. Hereditary ectodermal dysplasia: report of 11 patients from a family. Indian J Dent Res. 2013;24(4):502-6.

10. Dhanrajani PJ, Jiffry AO. Management of ectodermal dysplasia: a literature review. Dental update. 1998;25 (2):73-5.

11. Kupietzki A, Houpt M. Hypohidrotic ectodermal dysplasia: characteristics and treatment. Quintessence Int. 1995;26(4):285-91.

12. Bhargava A, Sharma A, Popli S, Bhargava R. Prosthodontic management of a child with ectodermal dysplasia: a case report. J Indian Prosthodont Soc. 2010;10 (2):137-40.

13. Araújo BF, Adelar BN, Marcon MZ, Medeiros DB, Araújo E, et al. Síndrome da displasia ectodérmica anidrótica no período neonatal relato de caso. J Pediatria. 2001;77(1):55.

14. Pedersen KE, Hallett KB. Treatment of multiple tooth ankylosis with removable prosthesis: case report. Pediatr Dent. 1994;16(2):136-8.

15. Rãducanu AM, Pãuna M, Feraru IV. A simple prosthetic restorative solution of a single peg-shaped upper central primary incisor in a case of ectodermal dysplasia. Romanian Journal of Morphology and Embryology. 2010;51(2):371-4.

16. Ferreira CS, Ferreira RAMH, Fernandes MLMF, Branco KMGR, Arantes RR, et al. Displasia Ectodérmica: relato de caso. Arq. Odontol. 2012; 48(1):47-52

17. Vasconcelos CM, Romero SSJ, Paiva CMF, Fonseca FT, Nunes AS, Carvalho S, et al. Hypohidrotic and hidrotic ectodermal dysplasia: a report of two cases. Dermatol Online J. 2013 Jul 14;19(7):18985

18. Lo Muzio L, Bucci P, Carife F, Ricctiello F, Scotti C, Rappelli G. Prosthetic rehabilitation of a child affected from anhydrotic ectodermal dysplasia: a case report. J Contemp Dent Pract. 2005;6(3):120-6.

19. Nowak AJ. Dental treatment for patients with ectodermal dysplasias. Birth Defects Orig Artic Ser. 1988;24(2);243-52.

20. Pigno MA, Blackman RB, Cronin RJ Jr, Cavazos E. Prosthodontic management of ectodermal dysplasia: a review of the literature. $\mathrm{J}$ Prosthet Dent. 1966;76(5): 541-5.

21. Della Valle D, Chevitarese AB, Maia LC, Farinhas JA. Alternative rehabilitation treatment for a patient with ectodermal dysplasia. J Clin Pediatr Dent. 2004;28(2):103-6. 
22. Silveira JM, Marrichi DMC, Santos ABCA, Gimenez T, Braga MM. Reabilitação estético-funcional de paciente com displasia ectodérmica em idade precoce. Rev Assoc Paul Cir Dent. 2012;66(1):42-7.

23. Ladda R, Gangadhar SA, Bhandari AJ. Prosthodontic Management of Hypohidrotic Ectodermal Dysplasia with Anodontia: a Case Report in Pediatric Patient and Review of Literature. Ann Med Health Sci Res. 2013;3(2):277-281.
24. Kaul S, Reddy R. Prosthetic rehabilitation of an adolescent with hypohidrotic ectodermal dysplasia with partial anodontia: case report. J Indian Soc Pedod Prev Dent. 2008;26(4):177-81.

25. Kramer FJ, Baethge C, Tschernitschek H. mplants in children with ectodermal dysplasia: a case report and literature review. Clin Oral Implants Res. 2007;18(1):140-6.

Dra. Viviane Cancio

\section{(Corresponding address)}

Universidade Federal Fluminense / Faculdade de Odontologia - Rua

Mário Santos Braga, $\mathrm{n}^{\circ} 30$ - Campus Valonguinho, Centro, Niterói, RJ, Brazil - CEP 24040-110

E-mail: vicancio@ig.com.br

Date submitted: 2018 Dec 26

Accept submission: 2019 Apr 04 